\title{
Retention-favorable timing of propagule release in barnacles and periwinkles
}

\author{
M. Bueno ${ }^{1}$, G. A. O. Moser $^{2}$, B. R. C. Tocci ${ }^{2}$, A. A. V. Flores ${ }^{1, *}$ \\ ${ }^{1}$ Centro de Biologia Marinha, Universidade de São Paulo, Rodovia Manoel Hipólito do Rego, Km 131,5, CEP 11600-000, \\ São Sebastião, SP, Brazil \\ ${ }^{2}$ Faculdade de Oceanografia, Universidade do Estado do Rio de Janeiro, Av. Francisco Xavier, 524, $4^{\circ}$ andar, Rio de Janeiro, \\ RJ, Brazil
}

\begin{abstract}
Recent studies on the ecology of marine larvae suggest that retention near coastal areas and self-recruitment are probably much more common than previously thought. In light of this, the advective potential of pelagic stages can be partially determined by the timing of propagule release. We sampled the upper-shore levels of a subtropical coastline in southeastern Brazil to examine the temporal patterns of propagule release for the common barnacle Chthamalus bisinuatus and the periwinkle Nodilittorina lineolata. The release timing in both species was very consistent between sites a few kilometers apart. Barnacles released nauplii in a rhythmic pattern, mostly coinciding with neap tides, when the speed of tidal currents was lowest. There was no variation in propagule release in relation to diel or flood-ebb tidal cycles. Periwinkles released propagules in a very irregular pattern, which remarkably matched a time series of wave heights. Egg capsules were released during periods of rough seas, when onshore surface currents were expected to prevail. Eggs were released mostly during ebb tides, and there was no diel variation. Propagule release rhythms are usually viewed as a means to ensure fast offshore advection, thus avoiding presumed hazardous conditions for larvae. However, propagule release strategies in these upper-shore species would more likely contribute to the retention of offspring close to parental stocks.
\end{abstract}

KEY WORDS: Reproductive timing $\cdot$ Propagule retention $\cdot$ Rocky shores

\section{INTRODUCTION}

Recent views of the evolution of complex life cycles in the marine environment (Pechenik 1999, Strathmann et al. 2002) emphasize that pelagic larval stages are independently selected because the pelagic habitat is more protected from predation than the benthos, especially for small offspring (Pechenik 1979, Allen \& McAlister 2007). The spatial distributions of larvae do not overlap those of juveniles and adults, decreasing the strength of intraspecific competition and cannibalistic interactions (Havenhand 1995). In this scenario, propagule release in the nearshore habitat may often be beneficial, and excessive dispersal away from the parental habitat may be disadvantageous for pelagic larval development. Broad-scale dispersal was believed to be a selective driving force shaping larval life histories of marine organisms. However, an in- creasing number of studies have recently provided independent evidence that many larvae and postlarvae may in fact use some predictable features of coastal and nearshore water circulation to promote their retention close to the parental habitat (e.g. Marliave 1986, Taylor \& Hellberg 2003, Almany et al. 2007, Morgan et al. 2009).

Within the intertidal zone, the timing of reproductive activities according to environmental cues may affect the extent of offshore advection of propagules. Because species with short-lived pelagic stages are prone to limited dispersal (Grantham et al. 2003), rates of self-replenishment can substantially increase if parents release their offspring at times when offshore and along-shore current speeds are lowest. Temporal patterns of larval release are extensively documented in the literature, but reports are heavily biased towards some invertebrate groups and laboratory studies (Mor- 
gan 1995). In the case of intertidal brachyuran crabs, an extensive dataset suggests that hatching is timed with different environmental cycles, so that optimal release is expected to take place during spring tides, at nocturnal ebbing periods, ensuring a fast offshore advection to a habitat patch where predation risk is lower (Forward 1987, Morgan 1995). By this means, larvae may easily be transported off coastal retention zones. However, intertidal crabs are mobile animals which can undertake tidal excursions prior to hatching and larval development is relatively long, usually lasting from 3 to $10 \mathrm{wk}$ (Hines 1986). In rocky shores, the most abundant organisms are sessile or sedentary, and their larvae develop relatively faster. Many of these animals also respond to environmental cues, which are far less predictable. For instance, phytoplankton blooms were shown to trigger spawning and larval release events in different marine invertebrates (Barnes 1962, Starr et al. 1990, 1991), and mechanical stimulation, which may simulate wave action, is frequently used to obtain gametes in mussels and polychaetes in the laboratory (e.g. Young 1945, Eckelbarger 1976). In such cases, ripe individuals must be capable of retaining their fully developed eggs until they perceive release-inducing stimuli. Because these environmental cues are highly stochastic, they are also very difficult to anticipate. Endogenous control in such species would explain little of their temporal release patterns.

Evidence of rhythmic spawning of gametes or larval hatching is usually obtained in the laboratory and mostly reveal different forms of endogenous control (e.g. Alifierakis \& Berry 1980, De Vries \& Forward 1989, Saigusa \& Kawagoye 1997). However, real temporal patterns can be quite different because environmental cues may completely override endogenous rhythms. Natural patterns can be spatially consistent for different groups (Gaudette et al. 2006, Flores et al. 2007); hence, underlying processes responsible for release activity may be the same over relatively large scales. Although still very scarce, information on the timing of propagule release by natural intertidal populations can be important in clarifying reproductive strategies and assessing dispersal potential, which is considered a key issue in conservation marine ecology.

The extent to which intertidal invertebrates rely on tidal cues to release their propagules may vary considerably in accordance with shore height. Accurate timing with tidal phase in mid and low-shore dwelling animals is crucial because propagules released during the flooding tide would face an unaffordable risk of being stranded. In the upper shore, brief immersion periods are restricted to spring tides and wave splash is the only means by which water may reach these shore levels during neap periods. Therefore, the risk of stranding is low and cross-shore advection due to tidal currents may not be substantially different for propagules that are released during these very brief ebb and flood-tide phases. In many wave-swept shores where the tidal range is low, the chthamalid barnacle zone may be located several centimeters above the mark of the highest astronomical water level (Venegas et al. 2002). Under these conditions, barnacles and other sessile organisms following a similar intertidal vertical range should release their propagules immediately upon contact with splashed water. There is no reason, therefore, to expect that release activities of uppershore invertebrates are restricted to spring tides, even if they were immersed only during this lunar phase. Thus, favorable conditions throughout the tide-amplitude cycle can be explored by high-shore organisms, resulting in either the export or retention of their offspring. To our knowledge, besides the work by Macho et al. (2005), there are no published reports of field measurements that may elucidate propagule release strategies for high-shore invertebrate assemblages.

The barnacle Chthamalus bisinuatus (Pilsbry) and the gastropod Nodilittorina lineolata (d'Orbigny) are dominant organisms in the upper mesolittoral and supralittoral zones, respectively, of the rocky intertidal along the southeastern Brazilian coast. There is no information on the larval ecology of these 2 species. Estimates of the larval development of tropical chthamalid barnacles (Yan \& Chan 2001, Yan 2003) range from 13 to $21 \mathrm{~d}$ (depending on temperature), which is a relatively short period compared to those in other invertebrates. Assessing the duration of pelagic stages of littorinids is far more difficult. Egg capsules are often released in the water and may take only 3 to $7 \mathrm{~d}$ to hatch; however, the duration of the veliger larva may vary from a few days to several weeks in temperate areas (Pilkington 1971, Fish \& Fish 1977, Son \& Hong 1998). This variation may be related to delayed metamorphosis in the absence of proper stimuli for settlement (Pechenik 1980), but may also be due to changes in other factors such as temperature and food supply. Because temperature largely determines larval development rate (O'Connor et al. 2007), we expect tropical littorinid larvae to develop more rapidly into competent stages in the presence of appropriate habitat cues.

In the first part of the study, we obtained daily temporal series of propagule release for the above species, and monitored key environmental variables that could explain variation in release rates in these 2 species. Two different natural populations, which were a few kilometers apart, were sampled to verify whether patterns were spatially consistent. As a second objective, a third location was chosen to determine whether rates of propagule release change according to the tidal 
(ebb vs. flood phases) or the day-night cycles. We used the results to identify which environmental factors might shape temporal variation in propagule release, and evaluate the reproductive strategy of these important rocky shore species, with emphasis on their dispersal potential.

\section{MATERIALS AND METHODS}

Study area. The study was conducted in different rocky shores along the littoral of São Paulo State (SP), which is located in the southeastern coast of Brazil (Fig. 1). In this region, the tidal regime is semidiurnal and the tidal range varies from 1.1 to $1.5 \mathrm{~m}$ during spring-tide periods. Time series of propagule release were obtained at 2 sites within Santos and São Vicente urban areas, namely at Ilha Porchat (a rocky outcrop forming a peninsula into the bay) and Emissário (an artificial jetty built on boulders), which host a well-developed intertidal community. Both are moderately exposed areas that mostly face wave action from the south (Emissário) or southeast (Ilha Porchat) (Fig. 1). Frequencies of propagule release according to the diel and tidal cycles were measured from populations at Zimbro $\left(23^{\circ} 49^{\prime} 26^{\prime \prime} \mathrm{S}, 45^{\circ} 25^{\prime} 10^{\prime \prime} \mathrm{W}\right)$, which is a sheltered rocky shore located $120 \mathrm{~km}$ north, in São Sebastião, SP.

Time series of propagule release. Sampling and laboratory analyses: Fieldwork consisted of daily visits to both shores around diurnal low tides from mid-summer (January 29, 2007) to early autumn (March 29, 2007), comprising 68 d. Sampling of biological data included the estimation of release rates of barnacle nauplii and periwinkle egg capsules, and the assessment of nearshore density of microphytoplankton. In both invertebrate species, daily release rates were obtained from adult individuals that were previously exposed to natural environmental variability within a spatial range of tens of meters. Confinement within sampling traps was restricted to a $1 \mathrm{~d}$ period prior to measurements. In the case of barnacles, different traps were set to cover this range, while periwinkles had to be removed from their natural habitat and placed in a collective trap.

We used the trap described by Bueno \& Flores (2008) to quantify naupliar release. Briefly, this is a sampling device that is directly screwed to a rock (enclosing a $9 \times 9 \mathrm{~cm}$ area), and includes a collecting tube at the lower end where larvae remain in seawater until the sample is recovered. A foam frame was used to seal the trap to the rock surface, thus minimizing larval loss. The trap was designed to be installed in vertical walls, so that water exchange was allowed through lateral and frontal apertures (screened with a $150 \mu \mathrm{m}$ mesh) in both the box that was attached to the rock and the collecting tube. Most of the trap surface was screened and water flow was therefore likely to be similar to that in the surrounding untouched rock surface. However, the screens provided some shade, which could reduce temperature variation inside the traps. At low tide, when samples were obtained, released materials accumulated in the lower $6 \mathrm{~cm}$ of the collecting tube. At each shore, 3 sampling areas of dense barnacle cover (80 to $90 \%$ ), which were separated by a distance of tens of meters, were established in an attempt to obtain a more general temporal pattern. In each of these areas, 10 contiguous trap positions delimiting sampling plots were set in 2 different rows to reduce the number of drilled holes while maintaining the traps in a narrow vertical range. A $5 \times 2$ arrangement was not always possible because irregular rock surface areas that prevented a tight fastening of the traps were

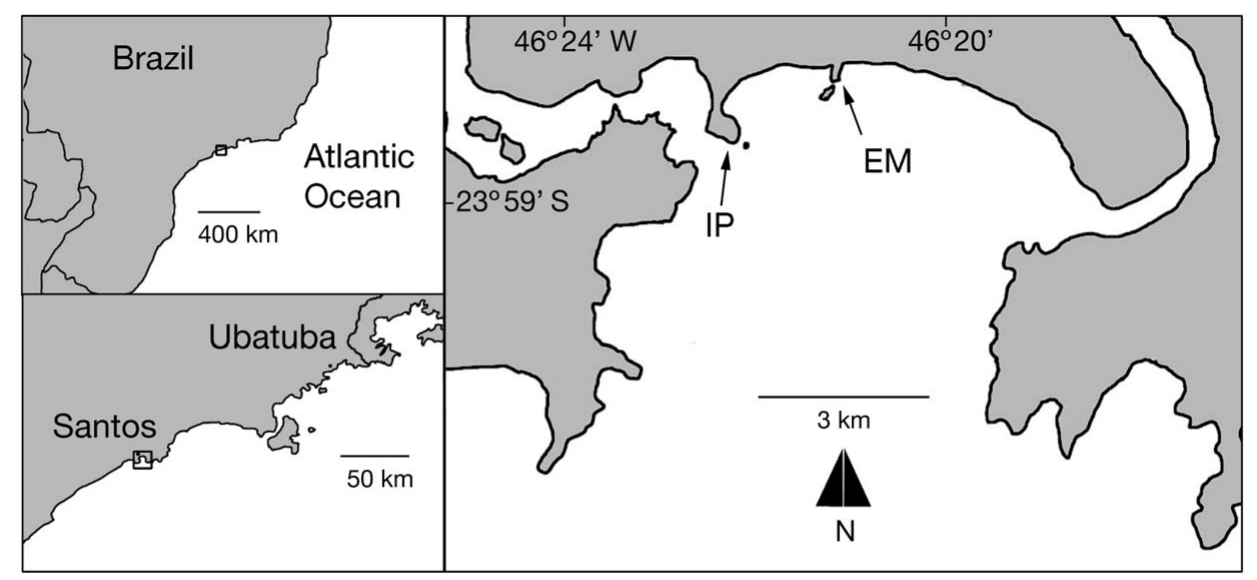

Fig. 1. Study area, indicating the sites where the temporal patterns of larval release were obtained. Ilha Porchat (IP) and Emissário (EM) are located in the São Vicente Island (right panel), which is a fully urbanized area straddling the counties of São Vicente and Santos, São Paulo, Brazil 
avoided. By sampling different barnacle plots, the negative effects of manipulation were greatly reduced. On any given day, only 1 trap at each of the 3 sampling areas was sampled for barnacle larvae; the remaining 9 positions were left untouched. The position of traps within areas was previously determined at random within blocks of $10 \mathrm{~d}$ without replacement, thus ensuring that no single plot could be sampled more than once during each of these $10 \mathrm{~d}$ periods, and $>7 \times$ during the whole study. After thorough rinsing of the collecting tubes, all retained materials were preserved in the field using a $70 \%$ ethanol solution and larvae were counted in the laboratory under a dissecting microscope. Eventual remnants within the square enclosure box could not be recovered because they had dried out by the time of sampling.

A different trap was used to estimate the release of egg capsules by periwinkles; this consisted of a PVC pipe ( $75 \mathrm{~cm}$ long, $4.5 \mathrm{~cm}$ diameter) that was attached to vertical rocky surfaces, as in the case of barnacles. Four circular windows $(5 \mathrm{~cm}$ diameter $)$ that were screened with a $150 \mu \mathrm{m}$ nylon mesh were evenly spaced along the trap to allow water flow. Removable plastic caps were used to close the trap at both ends. Snails inside such a device were more likely to experience an exchange of air, light and water comparable to that inside crevices, where most animals are found, but much less exchange compared to animals in open rock. A single trap was installed in a vertical position at each shore, covering the entire Chthamalus bisinuatus belt and the lower 30 to $40 \mathrm{~cm}$ of the supralittoral zone, encompassing most of the natural distribution of Nodilittorina lineolata at the study sites. Every day, groups of large snails $(\mathrm{n}=200$; shell height $>2 \mathrm{~mm}$ ) were randomly sampled along vertical transects in these same shores and placed inside the traps. Transects were established over a shoreline of 40 to $50 \mathrm{~m}$, and experimental snails were therefore originally subjected to variable environmental conditions. During low tides, when samples were processed in the field, the water retained in the lower $16 \mathrm{~cm}$ of the traps was sieved, and all materials released by snails over the preceding day were rinsed into vials and preserved. Before introducing a new group of individuals, the interior of the trap was cleaned with a pipe brush. Egg capsules were counted in the laboratory as above.

Because the density of microphytoplankton could trigger release activity, a $300 \mathrm{ml}$ surface water sample was collected each day at both shores to quantify the density of different taxonomic groups. All samples were preserved in neutralized $0.4 \%$ formalin, as described by Andersen \& Throndsen (2003), and planktonic particles were allowed to settle in a graduated cylinder over $4 \mathrm{~d}$. Most of the supernatant (75 to $90 \%$ ) was carefully suctioned, and the concentrated sample was resuspended and homogenized. A $1 \mathrm{ml}$ sample was then placed in a Sedgwick-Rafter chamber and cells were counted according to Guillard \& Sieracki (2005). At least 400 cells were counted in each sample, rendering error estimates of $\sim 10 \%$ (Lund et al. 1958). The phytoplankton was first classified into diatoms and dinoflagellates. Because Skeletonema cf. costatum (Grev.) Cleve prevailed throughout the study, this species was counted separately from other diatoms. However, correlation analyses were restricted to $S$. costatum because this was the only group in which temporal density variation was found to be consistent between sites $(\mathrm{r}=0.27, \mathrm{p}<0.05$; lag $1 \mathrm{~d})-\mathrm{a}$ characteristic that was also observed for the release of nauplii and egg capsules (see 'Results'). Because our capacity to process microphytoplankton samples was limited to a single daily sample at each shore, we cannot discount the possibility that other phytoplankton groups may have varied consistently in a similar way. The effect of these groups could not be properly assessed.

Data for physical variables were either obtained specifically for this study or accessed from publicdomain sources. Salinity data were recorded in situ using a YSI 30 probe. Salinity readings $(\mathrm{n}=3)$ were recorded at each shore and day, close to Chthamalus bisinuatus sampling areas and during diurnal low tides. Because sampling sites are not directly affected by estuarine waters, high-frequency salinity variation due to tidal exchange is negligible. Temporal trends would therefore mostly reflect movements of coastal and oceanic waters or wind-driven vertical mixing, which are processes with a typical duration of a few to several days. Time series of air temperature maxima and minima at a station in Santos were retrieved from the meteorological records of the Instituto Agronômico de Campinas, SP, Brazil, and series of wave height and orientation, which were estimated for the study area, were obtained from the NOAA database. Daily averages of tidal range were calculated from the tables published by the Brazilian Navy for the Santos harbor.

Numerical and statistical analyses: The time series of propagule release for both species were subjected to spectral analyses to discriminate harmonic components (Rayner 1971), and autocorrelation analyses were run to verify whether peaks in periodograms match significant correlations at corresponding lags. All time series were either log-transformed or firstdifferenced to meet the assumption of stationarity (Shumway \& Stoffer 2006). Then, autoregressive integrated moving average (ARIMA) models were fitted to the data according to autocorrelation functions (ACFs), and resulting white-noise series, i.e. series not showing significant lags in ACFs (Box et al. 1994), were used to test cross-correlations between sampled parameters. 
Because events of naupliar release tended to occur during periods of low tidal amplitude (see 'Results'), when desiccation at this tide level should be highest, the eventual effect of temperature was tested using simple correlation analyses between maximum records of larval delivery and average temperature values in the preceding 1 to $5 \mathrm{~d}$.

Diel and tidal variation of propagule release. Sampling: This part of the study was conducted during the summer of 2008, from January 14 to February 9. Within this period, we previously selected the days when high tides would reach the upper shore and then randomly chose five $3 \mathrm{~h}$ periods, centered on the time of high tide, within the dark and light phases. When sea level did not reach the expected high-tide water mark and the Chthamalus bisinuatus zone remained exposed, we postponed sampling until conditions allowed fieldwork. As a result, most sampling dates were clustered in 2 spring-tide periods, January 23 to 26 and February 7 to 9 , but occasional sampling took place in neap periods, at times of wind-driven positive anomaly (January 14 and 28). During each of these $3 \mathrm{~h}$ periods, plots were sampled at 15 min intervals. Diurnal sampling took place either during the early morning (05:45 to $08: 45 \mathrm{~h}$ ) or late afternoon (16:00 to $19: 00 \mathrm{~h}$ ), and nocturnal sampling occurred between 02:00 and 05:30 h. For both barnacles and snails, we used the same trap as above to estimate naupliar release, but in this case, the trap was installed upside down. The collecting tube was removed and a hose was connected in its place; the hose was then coupled to a manual pump that was fixed on the rocks $1 \mathrm{~m}$ above. Released materials therefore did not passively accumulate in the trap, but were actively pumped off at the time of sampling. Two different vertical areas that were spaced a few meters apart were delimited in the shore at 2 different levels: an upper level corresponding to the $C$. bisinuatus cover, 0.40 to $0.50 \mathrm{~m}$ above the mean tide level (MTL), and a lower level, $\sim 30 \mathrm{~cm}$ below, where the mytilid Brachidontes solisianus (d'Orbigny) prevails. Although reaching the lower B. solisianus cover, periwinkles are mostly found at the $C$. bisinuatus zone and above. However, we could not sample higher on the shore because snails that were held at more than $+0.70 \mathrm{~m}$ MTL would be hardly inundated. As above, contiguous trap positions were defined to reduce manipulation at any given plot. In this case, 6 positions were established at each area and level, following the procedure detailed above. Traps were held in the same position during each of the $3 \mathrm{~h}$ sampling periods and therefore a single plot could not be sampled more than twice. In each trap, 100 snails were added during each $3 \mathrm{~h}$ period. Egg capsules were counted for traps that were placed at both heights, but nauplii were only counted for traps that were installed at the higher shore level because density of adult barnacles at the lower level were too low to obtain adequate release records. At sampling, water was pumped repeatedly to ensure that all contents within the trap were renewed a few times. Suspended materials were retained in a sieve and preserved in $70 \%$ ethanol.

Statistical analyses: On some occasions, the water level did not reach the study areas over the whole period; hence, the number of 15 min samples varied among the flood and ebb phases (levels within 'tidal phase') within diurnal and nocturnal phases (levels within the 'diel' factor). A minimum of 2 and a maximum of 14 samples were obtained for each combination of 'diel' and 'tidal phase' in the case of barnacles, and 'tidal phase', 'diel' and 'shore height' (2 levels, high and low) in the case of snails. For each sampling period, counts of egg capsules or nauplii were averaged for each tidal phase, rendering 5 replicate observations for each analysis. Estimates of release were calculated as number of propagules per trap per hour. Data were analyzed according to fully orthogonal ANOVA models (2- and 3-way for barnacles and snails, respectively). In both cases, the variance differed among level combinations (Cochran's test, $0.01<$ $\mathrm{p}<0.05$ ), and the square-root transformation was only efficient in the case of Nodilittorina lineolata. The procedure was however maintained for Chthamalus bisinuatus because the sampling design was balanced and replication was relatively large $(n=5)$, thus allowing a safe interpretation of results (Underwood 1997).

\section{RESULTS}

\section{Time series of propagule release}

During fieldwork, calm waters were interrupted by periods of weak to moderate wave action (usually 4 to 6 d; Fig. 2a), which apparently affected nearshore conditions. Wave height was positively correlated with average salinity at sampled shores with no delay $(\mathrm{r}=$ 0.43, p < 0.05; Fig. 2a,b), and negatively correlated with the density of Skeletonema cf. costatum at a lag of $4 \mathrm{~d}$ $(\mathrm{r}=0.31, \mathrm{p}<0.05$; Fig. 2b,c), suggesting that surface waves may affect different water-column parameters.

\section{Chthamalus bisinuatus}

The temporal release pattern in this species was very similar at Ilha Porchat and Emissário. Spatial consistency is confirmed by cross-correlation analysis, which indicates maximum match at no lag (Fig. 3). There was a clear rhythmic pattern of release. Spectral analyses that was run for the average release at these sites 

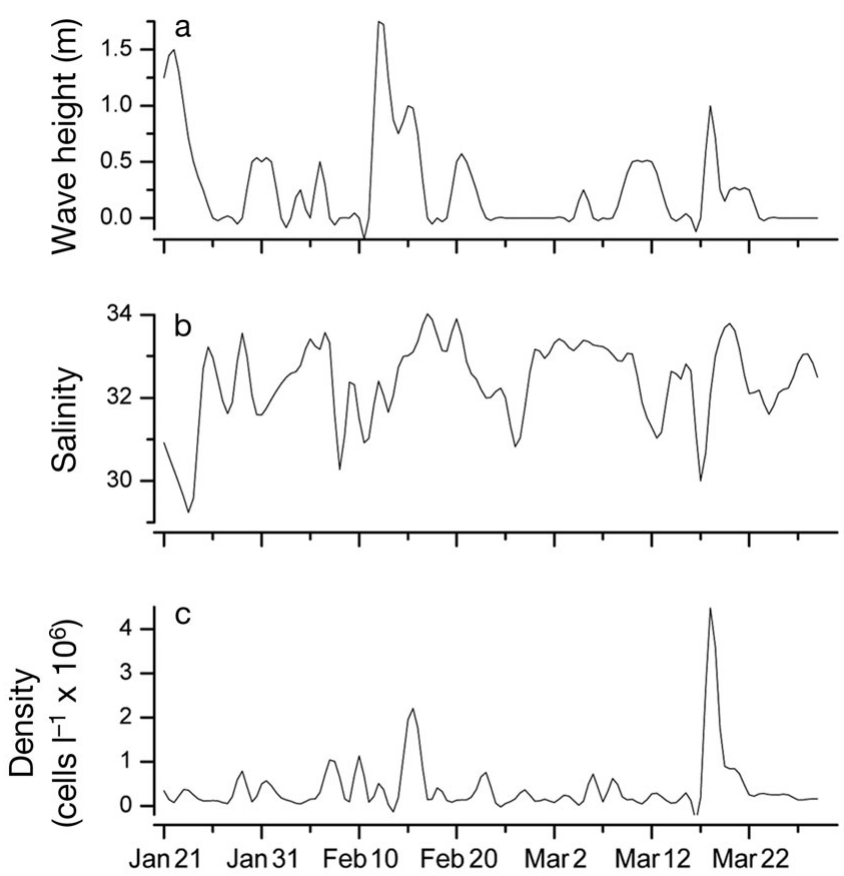

Fig. 2. Time series of (a) wave height, (b) salinity and (c) density of Skeletonema costatum cells over the study period. Salinity $(\mathrm{n}=6)$ and $S$. costatum $(\mathrm{n}=2)$ density values are averages for the 2 sampled shores

showed a clear peak at $11.3 \mathrm{~d}$, which closely matches significant auto-correlation coefficients at 12 and $13 \mathrm{~d}$ $(\mathrm{r}=0.28$ and 0.30 , respectively; $\mathrm{p}<0.05)$. The frequency of events was considerably larger than was expected for a semilunar pattern (14.8 d), but the crosscorrelation between the white-noise series of naupliar release and tidal range was significant at $7 \mathrm{~d}$ lag (Table 1, Fig. 4). Because this is nearly half of the semilunar period, such correlation could also translate to a negative one at no delay, indicating that nauplii are more frequently released during neap periods, as suggested in Fig. 4a. Barnacles also responded positively to salinity, but with a delay of $7 \mathrm{~d}$ (Table 1). Correlation coefficients between peaks of barnacle larval release and air temperature, which averaged from 27 to $31^{\circ} \mathrm{C}$, were all positive and relatively high for all preceding time windows ( 1 to $5 \mathrm{~d}, 0.36<\mathrm{r}<0.77$ ), but remained insignificant $(0.13<p<0.55)$, possibly due to the small sample size $(n=5)$. The highest correlation coefficient and smallest $\mathrm{p}$-value were obtained for temperature data for the 2 preceding days $(r=0.77, p=0.13)$.

\section{Nodilittorina lineolata}

Release for Nodilittorina lineolata was consistent between the sampled shores, but a 1 to 2 d delay was observed from Emissário to Ilha Porchat (Fig. 3). Harmonic components were not clear and their signifi- cance was not backed by autocorrelation analysis. The average time series using the data at these 2 sites was remarkably similar to the temporal variation in wave height (Fig. 5a). White-noise series of these 2 variables remained positively correlated at no lag (Fig. 5b, Table 1). Delayed egg capsule release at Ilha Porchat is apparently linked to the pattern of wave propagation in coastal waters. Waves invariably came first from the south (directly impacting Emissário) but shifted to the southeast (heading to Ilha Porchat; Fig. 1), and the average time they took to change direction was $\sim 2 \mathrm{~d}$ (Fig. 3). None of the remaining variables was significantly correlated with the rate of egg capsule release (Table 1).

\section{Diel and tidal variation of propagule release}

During the sampling period, average release rate for barnacles and snails was 9 nauplii $\mathrm{h}^{-1}$ and 43 egg capsules $h^{-1}$, respectively. No differences in the rate of naupliar release according to tidal or day-night cycles were observed (Table 2). For Nodilittorina lineolata, differences between diurnal and nocturnal release

Table 1. Cross-correlation analyses between average series of propagule release rates and environmental variables. Correlation coefficients $(\mathrm{r})$ and respective lags, in days (d), are provided for cases with statistical significance $(\mathrm{p}<0.05)$. ns: nonsignificant. S.: Skeletonema

\begin{tabular}{|lcc|}
\hline Variable & $\begin{array}{c}\text { Chthamalus bisinuatus } \\
\text { r/lag (d) }\end{array}$ & $\begin{array}{c}\text { Nodilittorina lineolata } \\
\text { r/lag (d) }\end{array}$ \\
\hline Tidal amplitude & $0.34 / 7$ & $\mathrm{~ns}$ \\
S. costatum & $\mathrm{ns}$ & $\mathrm{ns}$ \\
Wave height & $\mathrm{ns}$ & $0.49 / 0$ \\
Salinity & $0.35 / 7$ & $\mathrm{~ns}$ \\
\hline
\end{tabular}

Table 2. Results of factorial ANOVA models accounting for propagule release variation in relation to the diel and tidal cycles and, for Nodilittorina lineolata, in relation to shore level. C: Cochran's test for homoscedasticity. ns: nonsignificant; ${ }^{* *} \mathrm{p}<0.01$

\begin{tabular}{|c|c|c|c|c|c|c|}
\hline \multirow[t]{2}{*}{ Source } & \multicolumn{3}{|c|}{$\begin{array}{c}\text { Chthamalus } \\
\text { bisinuatus }\end{array}$} & \multicolumn{3}{|c|}{$\begin{array}{c}\text { Nodilittorina } \\
\text { lineolata }\end{array}$} \\
\hline & $\mathrm{df}$ & $F$ & $\mathrm{p}$ & $\mathrm{df}$ & $F$ & $\mathrm{p}$ \\
\hline Diel (D) & 1 & 1.79 & $\mathrm{~ns}$ & 1 & 1.34 & ns \\
\hline Tidal phase $(\mathrm{T})$ & 1 & 0.24 & $\mathrm{~ns}$ & 1 & 12.26 & ** \\
\hline Shore level (L) & - & - & - & 1 & 8.89 & ** \\
\hline $\mathrm{D} \times \mathrm{T}$ & 1 & 1.47 & ns & 1 & 1.32 & ns \\
\hline $\mathrm{D} \times \mathrm{L}$ & - & - & - & 1 & 1.49 & ns \\
\hline $\mathrm{T} \times \mathrm{L}$ & - & - & - & 1 & 1.12 & ns \\
\hline $\mathrm{D} \times \mathrm{T} \times \mathrm{L}$ & - & - & - & 1 & 0.39 & ns \\
\hline \multirow[t]{2}{*}{ Residual } & 16 & & & 32 & & \\
\hline & \multicolumn{3}{|c|}{$C=0.861 ; \mathrm{p}<0.01$} & \multicolumn{3}{|c|}{$C=0.382 ; \mathrm{ns}$} \\
\hline
\end{tabular}


a
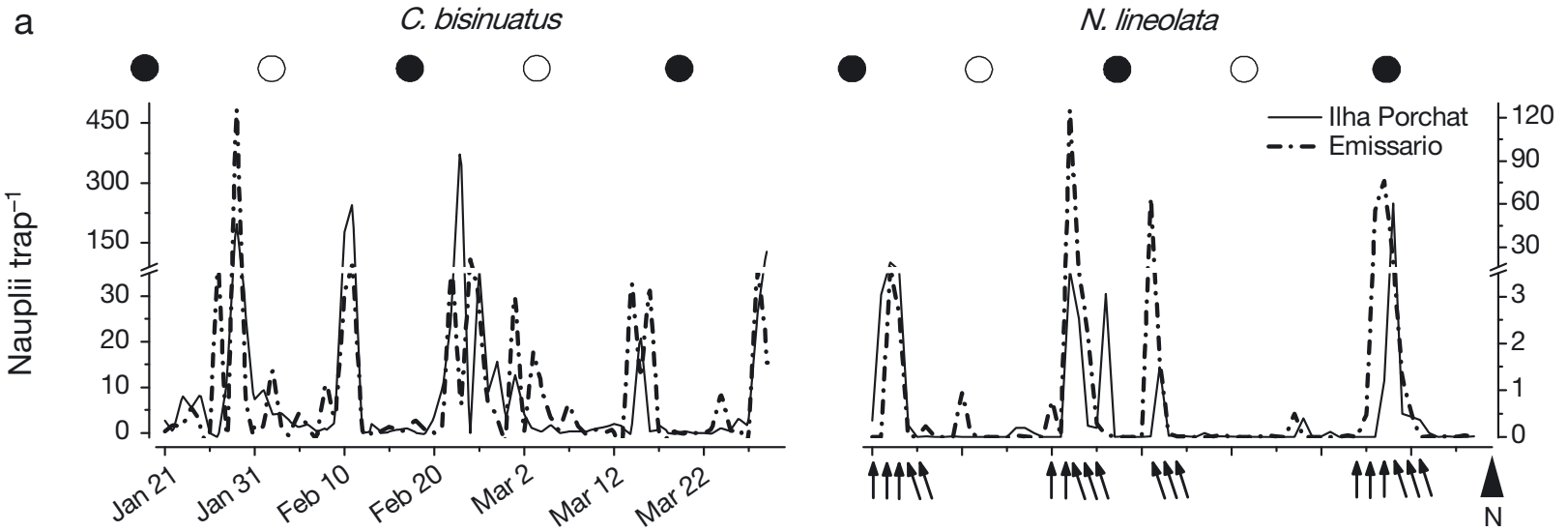

b

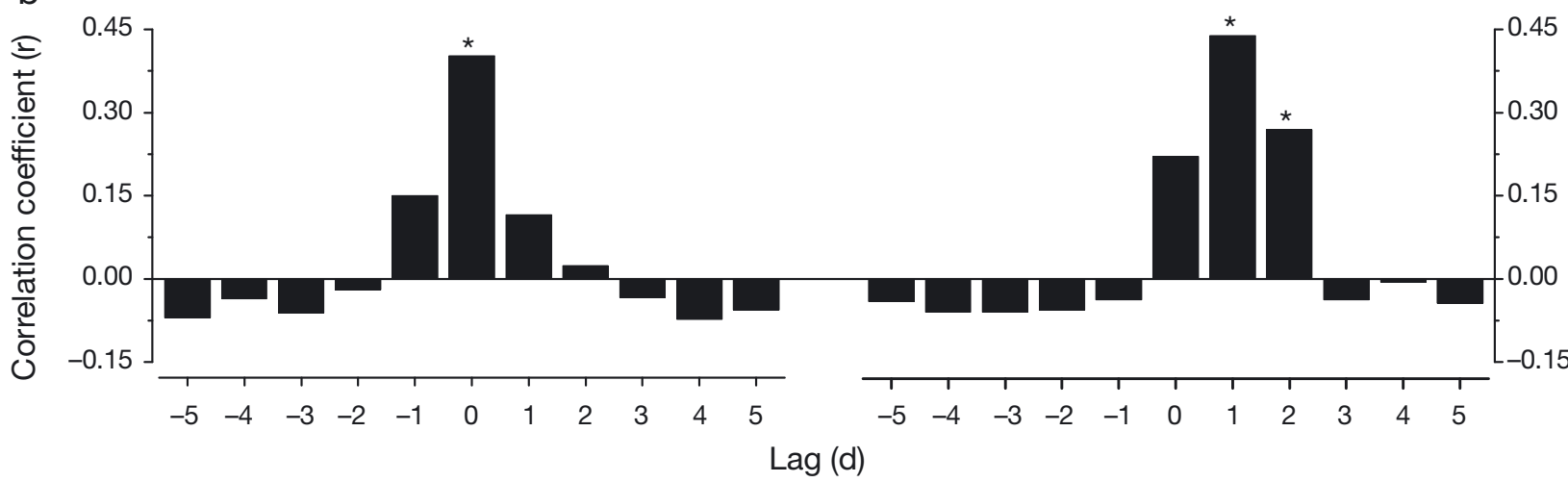

Fig. 3. Chthamalus bisinuatus and Nodilittorina lineolata. (a) Temporal patterns of propagule release at the study shores. Arrows below time series of egg capsule release for $N$. lineolata indicate the direction of wave propagation at the study area during main release events; 0 : new moon; O: full moon. (b) Cross-correlations show temporal consistency of release rates between sites for each species. ${ }^{*} \mathrm{p}<0.05$

rates were not detected, but there were significant differences in propagule release between shore levels and tidal phases (Table 2). Most eggs were released from snail populations at the upper shore. Regardless of shore level, egg release was over 4 times higher during ebb tides than during flood tides (Table 2, Fig. 6).

\section{DISCUSSION}

Intertidal barnacles and periwinkles living at the higher shore in this subtropical region exhibited contrasting temporal patterns of larval release. While Chthamalus bisinuatus nauplii were released in a clear periodic pattern, the egg capsules of Nodilittorina lineolata were released in a quite irregular manner. However, temporal patterns were remarkably consistent between sites for both species, indicating that factors inducing propagule release operated consistently at a spatial scale of at least a few kilometers. During the sampling period, properties of the water column appeared to change according to the tidal regime and wave action. Salinity covaried with tidal amplitude and was also positively correlated with wave height. Vertical mixing caused by disturbance of surface waves, or increasing tidal amplitude during spring tides, which are common processes in the nearshore (Mann \& Lazier 1991), could have caused an increase in surface salinity in the area. Due to extensive urban impact, bay waters surrounding our study sites are usually rich in nutrients and eutrophication is frequent (Braga et al. 2000). The input of organic matter was not measured in this study, but assuming that environmental conditions have not changed substantially, an additional supply of nutrients due to wave-driven mixing may have increased Skeletonema costatum standing stocks above stable levels, driving their collapse. This could explain the negative correlation that was found between wave height and $S$. costatum density, at a $4 \mathrm{~d}$ lag.

The proximate causes for the cyclic behavior that was observed in Chthamalus bisinuatus larval release are not clear. Most nauplii were released during neap tides and the pattern suggests control by the tidal- 
a
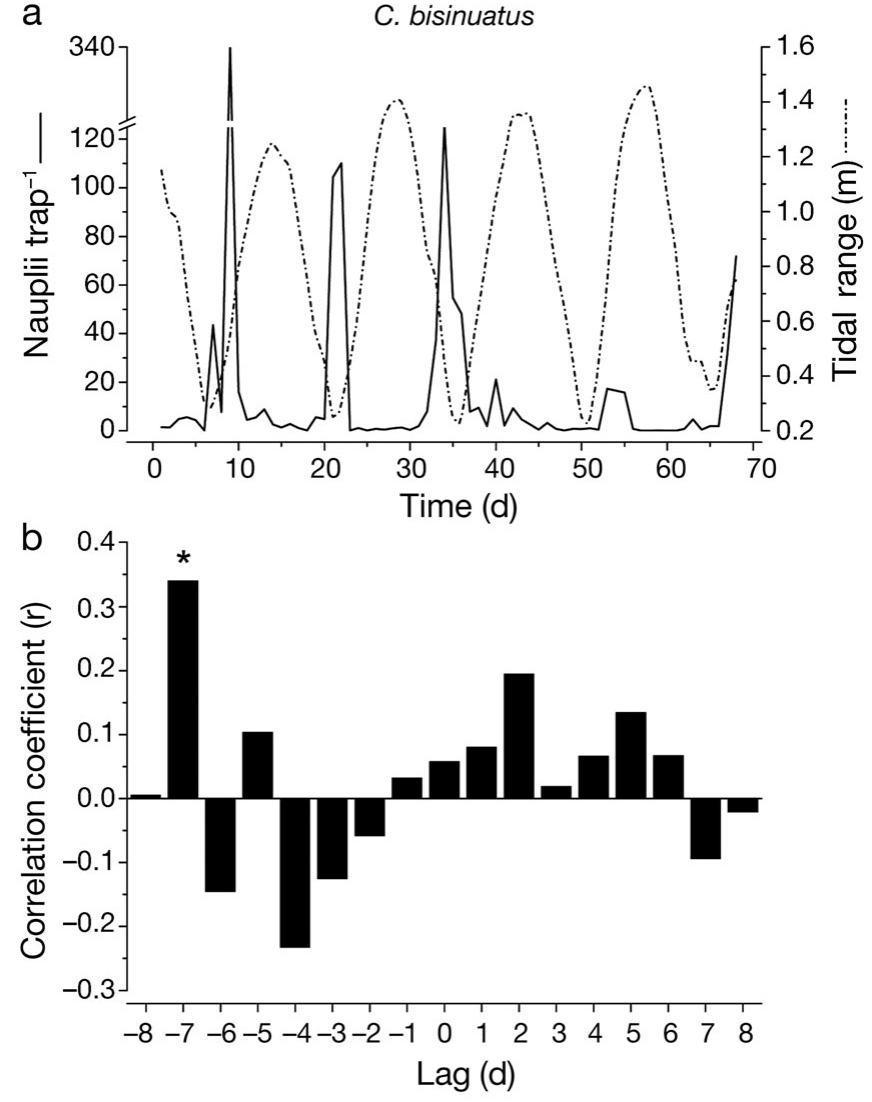

Fig. 4. Chthamalus bisinuatus. (a) Average time series of naupliar release ( $\mathrm{n}=6$ traps) at the sampling sites and tidal range in the study region. (b) Cross-correlation plot relating these variables. ${ }^{*} p<0.05$

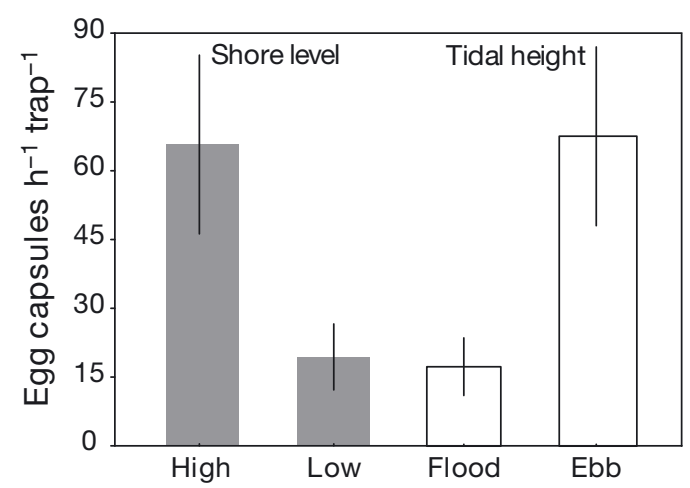

Fig. 6. Nodilittorina lineolata. Propagule release in relation to shore level and tidal height at the Zimbro shore, São Sebastião, SP, Brazil. Differences are statistically significant in both cases $(p<0.01)$. Error bars: \pm 1 SE

amplitude cycle. Many studies have highlighted the importance of monthly and fortnightly cycles in synchronizing reproductive activities in marine invertebrates (e.g. Korringa 1947, Palmer 1995, Naylor 2001), and their importance were already observed in intertidal barnacles (Macho et al. 2005). The latter authors

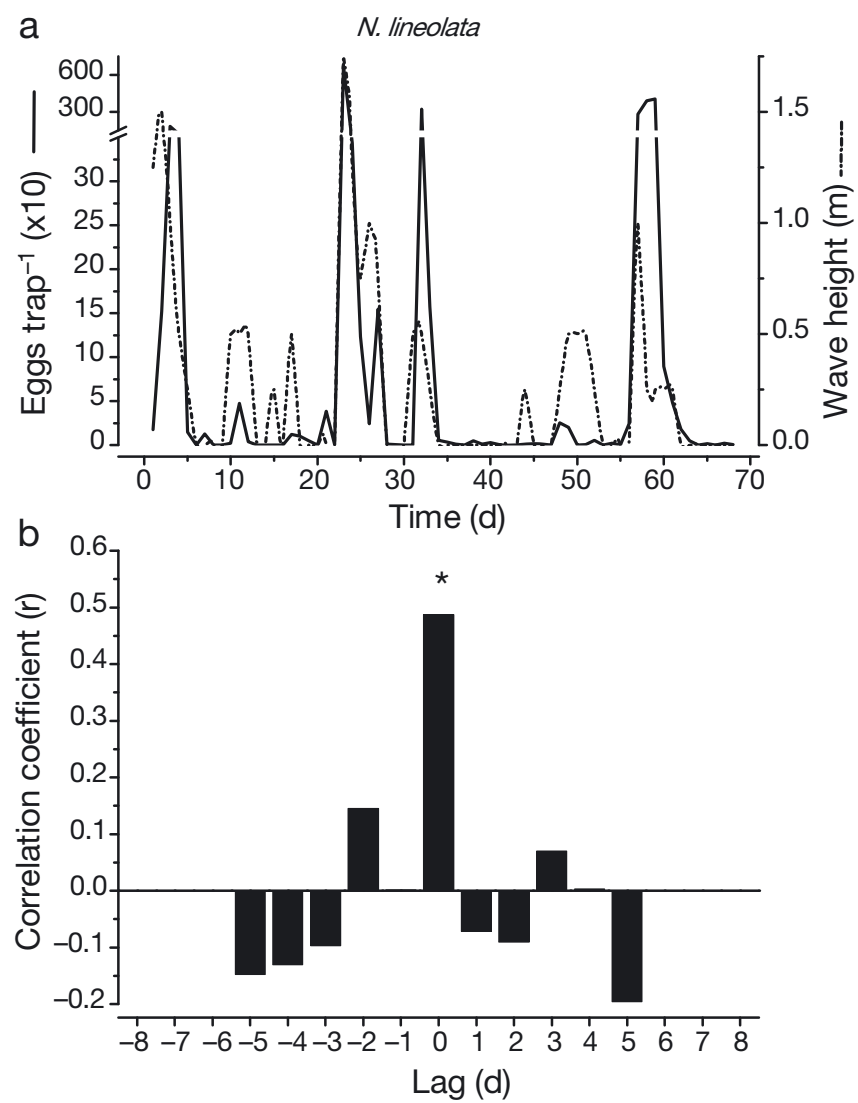

Fig. 5. Nodilittorina lineolata. (a) Average time series of egg capsule release ( $\mathrm{n}=2$ traps) at the sampling sites and wave height in the study region. (b) Cross-correlation plot relating these variables. ${ }^{*} \mathrm{p}<0.05$

found that chthamalid early nauplii were more abundant in nearshore waters during spring tides, which contrasted with our data showing the highest larval delivery during neap periods. In either case, it is difficult to hypothesize a plausible mechanism by which fortnightly release rhythms could be entrained in populations of high-shore barnacles. Moonlight cycles that are simulated in the laboratory can entrain semilunar larval release activity in populations of riverine crabs (Saigusa 1980). Recently, Forward \& Bourla (2008) have demonstrated that tidal-amplitude cycles of zoeal release can be set in a subtidal crab species by providing artificial oscillations of hydrostatic pressure in the laboratory. Moonlight and hydrostatic pressure would hardly entrain fortnight rhythmicity in upper-shore barnacles. Adult barnacles are sensitive to light, as they can withdraw their cirri into the shell when shaded (Millecchia \& Gwilliam 1972), and perception at light thresholds comparable to moonlight is possible, as evidenced for deep-water lobsters (Aguzzi et al. 2009). However, the opercula of upper-shore barnacles remain closed most of the time. Moreover, the height of 
the water column during brief immersion periods at the higher shore is apparently insufficient to deliver a pressure signal. In this study, we found a rhythmic pattern with a period of $\sim 11$ to $12 \mathrm{~d}$, which is substantially different from the $14.8 \mathrm{~d}$ that is expected for the fortnightly cycle.

It is possible that the periodic pattern of larval release in Chthamalus bisinuatus has nothing to do with environmental entrainment. Although insignificant probably due to the small sample size, the correlation we found between the magnitude of release events and the average air temperature over the 2 preceding days is positive and high. Excluding periods of extreme wind-driven sea level anomalies and rainfall, these barnacles would only get wet during neap-tide periods by wave splash. Desiccation stress is thus expected to increase steadily as the tides shift from spring to neap, and could trigger larval release. Clearly, the possible role of temperature in the regulation of naupliar release of chthamalid barnacles deserves further attention. Mass adult mortality after hot summer periods is frequent in our study region (pers. obs.); thus, delivery of larvae at a time when further survival chances are particularly low may increase their fitness.

Variation in the density of phytoplanktonic cells regulates spawning and larval release events for different cold-temperate invertebrate species (Barnes 1956, 1962, Smith \& Strehlow 1983, Starr et al. 1990, 1991, Wehrtmann 1994), blooms in cold-temperate regions being usually restricted to a very narrow season. Within a temporal scale of a few months, this would result in a highly stochastic pattern of release, not a rhythmic response as was observed in the present study. In addition, we found no correlation between naupliar release and the density of Skeletonema costatum, further suggesting that phytoplankton density did not elicit offspring delivery in Chthamalus bisinuatus. This is not surprising because seasonal variability of phytoplankton blooms in the subtropical coastline of Brazil is comparatively weak (Brandini et al. 2007); hence, larvae retained in coastal areas may find food supply year-round.

Unlike in the barnacle, the proximate driver of propagule delivery in Nodilittorina lineolata was clearly identified. Wave impact, under conditions ranging from calm to moderately agitated waters, apparently regulates egg capsule release rate. The higher the waves, the more intense was the delivery of propagules. Because the impact of waves was probably reduced inside the traps, it is likely that its effect was even higher than was estimated in this study. Since most of the releasing activity took place in the upper shore, breeding individuals preferably made use of wave splash to deliver their eggs in the water column instead of migrating to lower levels where predation risk was higher. Wave impact may significantly increase mortality risk of adults due to dislodgment. As in barnacles, intense offspring delivery during roughwater periods may be a means to maximize reproductive success in these snails.

Our results also show that release events can be desynchronized among sites by a few days depending on the orientation of the coastline. For any given wave height, maximum release will occur when waves travel in an orthogonal path relative to the shore. Because the wave path shifted almost invariably from south-north to southeast-northwest, release events at Ilha Porchat lagged by $2 \mathrm{~d}$ behind those at Emissário. Similar shifts in wave direction mediated by the passing of cold fronts have been reported at a site $\sim 130 \mathrm{~km}$ further north (Martins \& Mahiques 2006). This wave-driven stochastic pattern of propagule release lacks any apparent harmonic components, unlike the commonly observed fortnightly rhythms of other littorinids, both in the field and in the laboratory, when artificial tides are supplied (Fish 1979, Schmitt 1979, Alifierakis \& Berry 1980, Berry 1986). However, our results agree with those obtained by Pilkington (1971) for Melarapha spp., where the importance of wave action was also pointed out. Probably, temporal release patterns are not species-specific, but are most likely a habitatdriven feature. In microtidal regimes such as ours, the effect of wave action apparently supersedes the influence of tidal range. In areas where tidal amplitude is high and wave action is low, fortnightly rhythms such as those cited above may become more apparent.

Despite being strikingly different, the patterns reported for both barnacles and periwinkles apparently favor the retention of propagules in nearshore waters. In Chthamalus bisinuatus, naupliar release did not differ between ebbing and flooding tidal phases, but most delivery events were observed during neaptide periods, when offshore tidal currents are weaker. These results suggest that $C$. bisinuatus do not take advantage of differential tidal currents during the very brief periods when adults are submersed, but use neap-tide wave splash to release their larvae, which implies an immediate response upon contact with water. Most other coastal species in which tide-related cycles were examined follow a very different pattern, with propagules usually being released during springtide periods when tides start receding - a strategy which could minimize predation in the nearshore environment (as reviewed by Morgan 1995). However, there may be a trade-off between predation pressure and larval duration, so that for species undergoing relatively short pelagic development, the advantages of being retained close to shore may offset the cost of mortality due to predation. The epitoke swarming in 
the polychaete Eunice viridis (Caspers 1984) and spawning in the coral Goniastrea cf. favulus (Kojis \& Quinn 1982) are other examples of neap-tide release of reproductive products for invertebrate taxa undergoing short pelagic stages.

Retention-favorable propagule release by Nodilittorina lineolata is supposedly achieved not by avoiding tide-related offshore currents, but by delivering eggs during periods when average surface water movements are expected to be mostly shoreward. Periods of rough seas are usually associated with coastal downwelling. In our study system, cold fronts causing wave swell were associated with southerly winds (da Rocha et al. 2004), which produce shoreward Ekman transport of surface water and positive sea level anomalies (Carbonel 2003). As in N. lineolata, gamete release in the limpet Lottia digitalis and 11 other species of archaeogastropods worldwide is associated with rough water conditions and wind regimes favoring coastal downwelling (reviewed by Shanks 1998). Under these circumstances, propagules would be exposed either to onshore or along-shore compensating currents (Shanks 1998), but will not experience net offshore transport if maintained close to the surface. Their retention in nearshore waters would depend on the persistence of at least 2 different coastal features: a front delimiting the boundaries between the onshore-moving water mass and the oceanic water (Shanks 1998, McCulloch \& Shanks 2003), and a plume formed by coastal runoff due to rainfall (Garvine 1987, Washburn et al. 2003). The latter usually accompanies events of rough water during the passing of cold fronts in our study area. Their combined effects may produce retention-favorable conditions in coastal waters, thus decreasing advection to unsuitable habitat areas and enhancing settlement in areas close to the parental stock. Further information on the pelagic distribution of propagules and direct measurements of coastal currents will be crucial to confirm this retention mechanism.

Acknowledgements. Four different reviewers generously took their time for a very detailed reading of early drafts of this manuscript, and their thoughtful criticism resulted in a much improved paper. We also thank all lab colleagues for their invaluable help during fieldwork. Financial support was provided by FAPESP through a research grant to A.A.V.F. (\#2008/10085-5) and a MSc fellowship to M.B. (\#06/58700-4)

\section{LITERATURE CITED}

Aguzzi J, Sachez-Pardo J, García JA, Sardá F (2009) Day-night and depth differences in haemolymph melatonin of the Norway lobster, Nephrops norvegicus (L.). Deep-Sea Res I 56:1894-1905

Alifierakis NS, Berry AJ (1980) Rhythmic egg-release in Littorina littorea (Mollusca: Gastropoda). J Zool 190:297-307
Allen JD, McAlister JS (2007) Testing rates of planktonic versus benthic predation in the field. J Exp Mar Biol Ecol 347: 77-87

Almany GR, Berumen ML, Thorrold SR, Planes S, Jones GP (2007) Local replenishment of coral reef fish populations in a marine reserve. Science 316:742-744

Andersen P, Throndsen J (2003) Estimating cell numbers. In: Hallegraeff GM, Anderson DM, Cambella AD (eds) Manual on harmful microalgae. UNESCO, Paris, p 99-129

> Barnes H (1956) Balanus balanoides (L.) in the Firth of Clyde: the development and annual variation of the larval population, and the causative factors. J Anim Ecol 25:72-84

Barnes H (1962) Note on variations in the release of nauplii of Balanus balanoides with special reference to the spring diatom outburst. Crustaceana 4:118-122

Berry AJ (1986) Semi-lunar and lunar spawning periodicity in some tropical littorinid gastropods. J Molluscan Stud 52: $144-149$

Box GEP, Jenkins GM, Reinsel GC (1994) Time series analysis: forecasting and control. Prentice-Hall, NJ

Braga ES, Bonetti CVDH, Burone L, Bonetti J (2000) Eutrophication and bacterial pollution caused by industrial and domestic wastes at the Baixada Santista estuarine system-Brazil. Mar Pollut Bull 40:165-173

Brandini FP, da Silva AS, da Silva ET, Kolm H (2007) Sources of nutrients and seasonal dynamics of chlorophyll in the inner shelf off Paraná State-South Brazil Bight. J Coast Res 23:1131-1140

Bueno M, Flores AAV (2008) A sampling device to quantify offspring release of sessile marine invertebrates. Invertebr Reprod Dev 52:41-44

Carbonel CAAH (2003) Modelling of upwelling-downwelling cycles caused by variable wind in a very sensitive coastal system. Cont Shelf Res 23:1559-1578

> Caspers H (1984) Spawning periodicity and habitat of the palolo worm Eunice viridis (Polychaeta: Eunicidae) in the Samoan Islands. Mar Biol 79:229-236

> da Rocha RP, Sugahara S, da Silveira RB (2004) Sea waves generated by extratropical cyclones in the South Atlantic Ocean: hindcast and validation against altimeter data. Weather Forecast 19:398-410

> De Vries MC, Forward RB Jr (1989) Rhythms in larval release of the sublittoral crab Neopanope sayi and the supralittoral crab Sesarma cinereum (Decapoda, Brachyura). Mar Biol 100:241-248

Eckelbarger KJ (1976) Larval development and population aspects of the reef-building polychaete Phragmatopoma lapidosa from the east coast of Florida. Bull Mar Sci 26: $117-132$

Fish JD (1979) The rhythmic spawning behaviour of Littorina littorea (L.). J Molluscan Stud 45:172-177

- Fish JD, Fish S (1977) The veliger larva of Hydrobia ulvae with observations on the veliger of Littorina littorea (Mollusca: Prosobranchia). J Zool 182:495-503

> Flores AAV, Mazzuco ACA, Bueno M (2007) A field study to describe diel, tidal and semilunar rhythms of larval release in an assemblage of tropical rocky shore crabs. Mar Biol 151:1989-2002

Forward RB Jr (1987) Larval release rhythms of decapod crustaceans: an overview. Bull Mar Sci 41:165-176

Forward RB Jr, Bourla MH (2008) Entrainment of the larval release rhythm of the crab Rhithropanopeus harrisii (Brachyura: Xanthidae) by cycles in hydrostatic pressure. J Exp Mar Biol Ecol 357:128-133

> Garvine RW (1987) Estuary plumes and fronts in shelf waters: a layer model. J Phys Oceanogr 17:1877-1896 
Gaudette J, Wahle RA, Himmelman JA (2006) Spawning events in small and large populations of the green sea urchin Strongylocentrotus droebachiensis as recorded using fertilization assays. Limnol Oceanogr 51: 1485-1496

Grantham BA, Eckert GL, Shanks AL (2003) Dispersal potential of marine invertebrates in diverse habitats. Ecol Appl 13:S108-S116

Guillard RRL, Sieracki MS (2005) Counting cells in cultures with the light microscope. In: Andersen RA (ed) Algal culturing techniques. Elsevier Academic Press, Burlington, MA, p 239-252

Havenhand JN (1995) Evolutionary ecology of larval types. In: McEdward L (ed) Ecology of marine invertebrate larvae. CRC Press, Boca Raton, FL, p 79-122

Hines AH (1986) Larval patterns in the life histories of brachyuran crabs (Crustacea, Decapoda, Brachyura). Bull Mar Sci 39:444-466

Kojis BL, Quinn NJ (1982) Reproductive ecology of two faviid corals (Coelenterata: Scleractinia). Mar Ecol Prog Ser 8: 251-255

Korringa P (1947) Relations between the moon and periodicity in the breeding of marine animals. Ecol Monogr 17: $349-381$

Lund JWG, Kipling C, LeCren ED (1958) The inverted microscope method of estimating algal numbers and the statistical basis of estimations by counting. Hydrobiologia 11: 143-170

Macho G, Molares J, Vázquez E (2005) Timing of larval release by three barnacles from the NW Iberian Peninsula. Mar Ecol Prog Ser 298:251-260

Mann KH, Lazier JRN (1991) Dynamics of marine ecosystems: biological-physical interactions in the oceans. Blackwell Science, Boston, MA

Marliave JB (1986) Lack of planktonic dispersal of rocky intertidal fish larvae. Trans Am Fish Soc 115:149-154

Martins CC, Mahiques MM (2006) Small-scale beach rotation process on a reflective beach. J Coast Res 39(Suppl): 542-546

McCulloch A, Shanks AL (2003) Topographically generated fronts, very nearshore oceanography and the distribution and settlement of mussel and barnacle cyprids. J Plankton Res 25:1427-1439

Millecchia R, Gwilliam GF (1972) Photoreception in a barnacle: electrophysiology of the shadow reflex pathway in Balanus cariosus. Science 177:438-441

Morgan SG (1995) The timing of larval release. In: McEdward L (ed) Ecology of marine invertebrate larvae. CRC Press, Boca Raton, FL, p 157-191

- Morgan SG, Fisher JL, Miller SH, McAfee ST, Largier JL (2009) Nearshore larval retention in a region of strong upwelling and recruitment limitation. Ecology 90: 3489-3502

Naylor E (2001) Marine animal behaviour in relation to lunar phase. Earth Moon Planets 85-86:291-302

> O'Connor MI, Bruno JF, Gaines SD, Halpern BS, Lester SE, Kinlan BP, Weiss JM (2007) Temperature control of larval dispersal and the implications for marine ecology, evolution, and conservation. Proc Natl Acad Sci USA 104: $1266-1271$

Palmer J (1995) The biological rhythms and clocks of intertidal animals. Oxford University Press, New York, NY

Pechenik JA (1979) Role of encapsulation in invertebrate life histories. Am Nat 114:859-870

Pechenik JA (1980) Growth and energy balance during the larval lives of three prosobranch gastropods. J Exp Mar Biol Ecol 44:1-28

Pechenik JA (1999) On the advantages and disadvantages of larval stages in benthic marine invertebrate life cycles. Mar Ecol Prog Ser 177:269-297

Pilkington MC (1971) Eggs, larvae, and spawming in Melarapha cincta (Quoy \& Gaimard) and M. olivieri Finlay (Littorinidae, Gastropoda). Aust J Mar Freshw Res 22:79-90

Rayner JN (1971) An introduction to spectral analysis. Pion Press, London

Saigusa M (1980) Entrainment of a semilunar rhythm by simulated moonlight cycle in the terrestrial crab Sesarma haematocheir. Oecologia 46:38-44

> Saigusa M, Kawagoye O (1997) Circatidal rhythm of an intertidal crab, Hemigrapsus sanguineus: synchrony with unequal tide height and involvement of a light-response mechanism. Mar Biol 129:87-96

Schmitt RJ (1979) Mechanics and timing of egg capsule release by the littoral fringe periwinkle Littorina planaxis (Gastropoda: Prosobranchia). Mar Biol 50:359-366

> Shanks AL (1998) Apparent oceanographic triggers to the spawning of the limpet Lottia digitalis (Rathke). J Exp Mar Biol Ecol 222:31-41

Shumway RH, Stoffer DS (2006) Time series analysis and its applications. Springer, New York, NY

Smith JR, Strehlow DR (1983) Algal-induced spawning in the marine mussel Mytilus californianus. Int J Invertebr Reprod 6:129-133

Son MH, Hong SY (1998) Reproduction of Littorina brevicula in Korean waters. Mar Ecol Prog Ser 172:215-223

Starr M, Himmelman JH, Therriault JC (1990) Direct coupling of marine invertebrate spawning with phytoplankton blooms. Science 247:1071-1074

Starr M, Himmelman JH, Therriault JC (1991) Coupling of nauplii release in barnacles with phytoplankton blooms-a parallel strategy to that of spawning in urchins and mussels. J Plankton Res 13:561-571

Strathmann RR, Hughes TR, Kuris AM, Lindeman KC, Morgan SG, Pandolfi JM, Warner RR (2002) Evolution of local recruitment and its consequences for marine populations. Bull Mar Sci (Suppl) 70:377-396

Taylor MS, Hellberg ME (2003) Genetic evidence for local retention of pelagic larvae in a Caribbean reef fish. Science 299:107-109

Underwood AJ (1997) Experiments in ecology: their logical design and interpretation using analysis of variance. Cambridge University Press, Cambridge

> Venegas RM, Navarrete SA, Finke GR (2002) A simple and inexpensive device to measure immersion times in wave exposed shores. J Mar Biol Assoc UK 82:1023-1026

Washburn L, McClure KA, Jones BH, Bay SM (2003) Spatial scales and evolution of stormwater plumes in Santa Monica Bay. Mar Environ Res 56:103-125

Wehrtmann IS (1994) Larval production of the caridean shrimp, Crangon septemspinosa, in waters adjacent to Chesapeake Bay in relation to oceanographic conditions. Estuaries 17:509-518

Yan Y (2003) Larval development of the barnacle Chinochthamalus scutelliformis (Cirripedia: Chthamalidae) reared in the laboratory. J Crustac Biol 23:513-521

Yan Y, Chan BKK (2001) Larval development of Chthamalus malayensis (Cirripedia: Thoracica) reared in the laboratory. J Mar Biol Assoc UK 81:623-632

> Young RT (1945) Stimulation of spawning in the mussel (Mytilus californianus). Ecology 26:58-69

Submitted: February 4, 2010; Accepted: June 25, 2010

Proofs received from author(s): August 19, 2010 